J. Clin. Chem. Clin. Biochem.

Vol. 17, 1979, pp. 553-563

\title{
Comparison of 9 Methods for the Determination of Cholesterol
}

\author{
By R. Haeckel, O. Sonntag, W. R. Külpmann and U. Feldmann \\ Institut für Klinische Chemie und Institut für Biometrie der Medizinischen Hochschule Hannover
}

(Received November 7, 1978/February 16, 1979)

Summary: Seven enzymatic procedures for the determination of cholesterol in serum were compared with the Liebermann-Burchard- and a gas-chromatographic method. Using a decision matrix all methods could be ranked according to reliability and practicability. With the exception of the cholesterol oxidase-coupled Kageyama principle and the Liebermann-Burchard procedure, all the other methods showed similar reliability.

\section{Vergleich von 9 Methoden zur Bestimmung von Cholesterin}

Zusammenfassung: Sieben enzymatische Verfahren zur Bestimmung der Cholesterin-Konzentration im Serum wurden mit der Liebermann-Burchard- und einer gaschromatographischen Methode verglichen. Mit Hilfe einer Entscheidungsmatrix wurde eine Wichtung von Ergebnissen und Praktikabilität versucht. Dabei zeigt sich, daß sich mit Ausnahme des mit Cholesterinoxidase gekoppelten Kageyama- und des Liebermann-Burchard-Prinzips die übrigen Methoden etwa gleich zuverlässig verhielten.

\section{Introduction}

For many years, cholesterol was determined chiefly by the Liebermann-Burchard and the Zak methods. Both procedures are prone to various interferences, which are summarized in several reviews (1-5). In addition, they use a strong acidic milieu, a disadvantage which is particularly relevant in mechanised analytical systems, because of corrosion.

After Richmond $(6,7)$, in 1972, reported the isolation of a bacterial cholesterol oxidase, various procedures were soon developed for the determination of cholesterol with the aid of this enzyme. In the meantime, in many laboratories, the enzymatic methods have replaced the older procedures mentioned above. They appear to be more specific and better suited for mechanisation.

The various enzymatic methods differ with respect to the coupled indicator reaction (table 1). After hydrolysis of cholesterol esters in the presence of cholesterol esterase, cholesterol oxidase activates the oxidation of cholesterol to $\Delta^{4}$-cholestenon. The resulting $\mathrm{H}_{2} \mathrm{O}_{2}$ is measured in most procedures.

For comparison, we selected 3 test kits based on Trinder's reaction (8), but with differences in the reaction mixture, one test kit applying the Hantzsch reaction according to Kageyama (9), one test kit using the NADP-coupled alde- hyde dehydrogenase reaction (10) and one test kit following the principle first described by Harders \& Helger (11). In addition the Liebermann-Burchard procedure and a gas chromatographic method were included in this study. The last method was primarily used to investigate the accuracy of the other tests. In an earlier report we found, in accordance with Allain et al. (12), that the procedure of $A$ bell et al. (13) often recommended for reference purposes, leads to cholesterol values which are approximately $10 \%$ higher than those determined with enzymatic methods.

\section{Materials and Methods}

Enzymatic methods

All enziymatic methods were performed with commercially available test kits. The abbreviations used and some relevant data are summarized in table 1 . Concentrations of the various components are listed in table 2 only for the Trinder principle, because the test combinations chosen show significant differences. For further details, see the information distributed by the manufacturers. All test kits were used as supplied by industry without further modifications. With the Kageyama procedure the incubation period was extended to 75 minutes according to l.c. (32). The ABA 100 and Labtronic ES 25 system were set up as reported in table 3 and 4.

Liebermann-Burchard procedure

The Liebermann-Burchard reaction was performed with a SMA $12 / 60$ from Technicon (Technicon GmbH, D-6368 Bad Vilbel) 
Table 1: Methods for the determination of the cholesterol concentration

\begin{tabular}{|c|c|c|c|c|c|c|c|c|c|c|}
\hline $\begin{array}{l}\text { Method } \\
\text { number }\end{array}$ & $\begin{array}{l}\text { Abbreviation } \\
\text { used }\end{array}$ & Principle & $\begin{array}{l}\text { Source } \\
\text { of } \\
\text { reagents }\end{array}$ & $\begin{array}{l}\text { Cata- } \\
\text { logue } \\
\text { number } \\
\text { of test } \\
\text { kit }\end{array}$ & $\begin{array}{l}\text { Lot } \\
\text { number } \\
\text { of test } \\
\text { kit }\end{array}$ & $\begin{array}{l}\text { Analyt- } \\
\text { ical } \\
\text { system }\end{array}$ & $\begin{array}{l}\text { Meas- } \\
\text { uring } \\
\text { wave- } \\
\text { length } \\
(\mathrm{nm})\end{array}$ & $\begin{array}{l}\text { Incuba- } \\
\text { tion } \\
\text { temper- } \\
\text { ature } \\
\left({ }^{\circ} \mathrm{C}\right)\end{array}$ & $\begin{array}{l}\text { Incuba- } \\
\text { tion } \\
\text { time } \\
\text { (min) }\end{array}$ & $\begin{array}{l}\text { Sample } \\
\text { volume } \\
(\mu \mathrm{l})\end{array}$ \\
\hline 1 & $\begin{array}{l}\text { 4-Aminophena- } \\
\text { zone (PAP) }\end{array}$ & $\begin{array}{l}\left.\mathrm{ChO}+\mathrm{ChE}^{1}\right) \\
\text { and Trinder's } \\
\text { reaction (12) }\end{array}$ & $\mathrm{BM}^{2}$ ) & 172626 & 1277516 & $\left.\operatorname{ES} 25^{8}\right)$ & Hg 546 & 37 & 15 & 10 \\
\hline 2 & Kageyama & $\begin{array}{l}\mathrm{ChO}+\mathrm{ChE} \\
\text { and Kageyama's } \\
\text { principle (9) }\end{array}$ & $\mathrm{BM}^{2}$ ) & 124079 & 64382501 & $1 \mathrm{ES} 25^{8}$ ) & $\mathrm{Hg} 405$ & 37 & 75 & 20 \\
\hline 3 & Merckotest & $\begin{array}{l}\mathrm{ChO}+\mathrm{ChE} \\
\mathrm{I}^{-} \stackrel{\mathrm{H}_{2} \mathrm{O}_{2}}{\longrightarrow} \mathrm{I}_{2}\end{array}$ & Merck $^{3}$ ) & 14350 & 7500272 & $\operatorname{ES~} 25^{8}$ ) & $\mathrm{Hg} 365$ & 25 & 30 & 10 \\
\hline 4 & $\begin{array}{l}\text { Aldehyde dehydro- } \\
\text { genase (AIDH) }\end{array}$ & $\begin{array}{l}\text { ChO + ChE } \\
\text { AlDH-method } \\
\text { according to } \\
\text { Haeckel \& } \\
\text { Perlick (10) }\end{array}$ & $\left.{ }^{4}\right)$ & & & $\operatorname{ES} 25^{8}$ ) & $\mathrm{Hg} 334$ & 37 & 10 & 10 \\
\hline 5 & $\mathrm{ABA}$ & $\begin{array}{l}\text { ChO + ChE } \\
\text { AlDH-method } \\
\text { according to } \\
\text { Haeckel \& Perlick } \\
\text { (10) }\end{array}$ & 4) & & & $\begin{array}{l}\text { ABA } \\
\left.100^{5}\right)\end{array}$ & $340 / 380$ & 37 & 10 & 5 \\
\hline 6 & GENT & $\begin{array}{l}\text { ChO + ChE and } \\
\text { Trinder's reaction }\end{array}$ & Abbott ${ }^{5}$ ) & 6095 & $\begin{array}{l}220 \\
\mathrm{~A} 11 \overline{7} 7 \mathrm{~N}\end{array}$ & $\begin{array}{l}\mathrm{ABA} \\
\left.100^{5}\right)\end{array}$ & $500 / 600$ & 37 & 10 & 5 \\
\hline 7 & AA & $\begin{array}{l}\text { ChO + ChE } \\
\text { Technicon and } \\
\text { Trinder's } \\
\text { reaction (12) }\end{array}$ & $\begin{array}{l}\text { Techni- } \\
\operatorname{con}^{6} \text { ) }\end{array}$ & $\begin{array}{l}\text { T21- } \\
0690-54 \\
T 21- \\
0888\end{array}$ & $\begin{array}{l}1066102 \\
1327125\end{array}$ & $\left.A A I^{6}\right)$ & 525 & 37 & 9 & 200 \\
\hline 8 & SMA & $\begin{array}{l}\text { Liebermann- } \\
\text { Burchard }\end{array}$ & $\begin{array}{l}\text { Merz u. } \\
\text { Dade }^{7} \text { ) }\end{array}$ & - & - & $\begin{array}{l}\text { SMA } \\
\left.12 / 60^{6}\right)\end{array}$ & 630 & $\begin{array}{l}\text { room } \\
\text { temper- } \\
\text { ature }\end{array}$ & 9 & 2000 \\
\hline 9 & GC & $\begin{array}{l}\text { Gas-chromato- } \\
\text { graphy }\end{array}$ & - & - & - & \multicolumn{2}{|c|}{$\begin{array}{l}\text { Research }{ }^{9} \text { ) - } \\
\text { Gas } \\
\text { Chromato- } \\
\text { graph } \\
5750\end{array}$} & - & - & 200 \\
\hline
\end{tabular}

1) Cholesterol oxidase + cholesterol esterase. ${ }^{2}$ ) BM, Boehringer Mannheim (D-6800 Mannheim). ${ }^{3}$ ) Merck AG (D-6100 Darmstadt) $\left.{ }^{4}\right)$ Reaction mixture was prepared according to $1 . c .(10){ }^{5}$ ) Abbott GmbH (D-6070 Langen) ${ }^{6}$ ) AA II, cartridge No. 170-106-01 and SMA 12/60, cartridge No. 157A058, Technicon GmbH (D-6368 Bad Vilbel). ${ }^{7}$ ) Merz und Dade GmbH (D-8000 München 50). ${ }^{8}$ ) Labtronic GmbH (D-6239 Vockenhausen) ${ }^{9}$ ) Hewlett Packard (D-7030 Böblingen).

Table 2: Contents of the assay mixture of test kits from various manufacturers using the Trinder reaction.

\begin{tabular}{llll}
\hline Method $^{1}$ ) & $\begin{array}{l}\text { 4-Amino- } \\
\text { phenazone }\end{array}$ & GENT & AA \\
\hline Potassium phosphate, mmol/1 & 390 & 50 & 400 \\
pH & 7.7 & 6.7 & 7.2 \\
Phenol, mmol/1 & 9.85 & 13.86 & 6.42 \\
4-Aminophenazone, mmol/1 & 0.99 & 0.79 & 3.84 \\
Methanol, mmol/1 & 920.4 & - & 967.5 \\
Hydroxypolyethoxydodecane, \% & 0.2 & - & - \\
Surfactant, \% & - & - & 3.9 \\
Sodium cholate, mmol/1 & - & 2.97 & - \\
Carbowax-6000, mmol/1 & - & 0.2 & - \\
Peroxidase, U/1 & 39 & 27393 & 2260 \\
Cholesterol oxidase, U/1 & 59 & 165 & 191 \\
Cholesterol esterase, U/1 & 197 & 116 & 136 \\
\hline
\end{tabular}

1) For explanation of abbreviations see table.1

using method No. N-24 a. The reagents were purchased from Merz und Dade (D-8000 Munich).

\section{Gas chromatography}

For gas chromatography we used the method of Siekmann et al (14). The derivatisation was found to be unnecessary; and was omitted. Sample preparation: $200 \mu \mathrm{l}$ serum and $1000 \mu \mathrm{l} \mathrm{KOH}$
Table 3: Protocol of the ABA 100

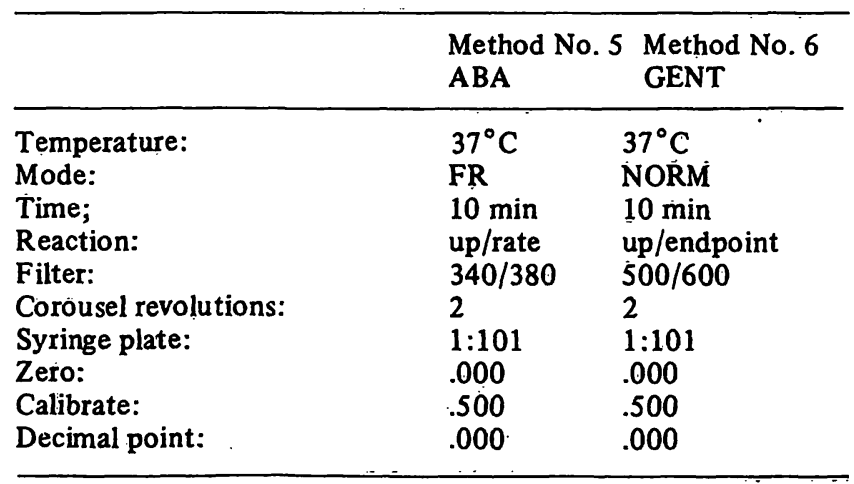

$(0.5 \mathrm{~mol} / \mathrm{l})$ in ethanol were incubated $30 \mathrm{~min}$ at $56^{\circ} \mathrm{C}$. After cooling to room temperature $6 \mathrm{ml}$ cyclohexane were àdded. The mixture was vigorously shaken for $5 \mathrm{~min}$ and then centrifugated at 4000 r.p.m. ( $5 \mathrm{~min}$ ). Four $\mathrm{ml}$ of the cyclohexane phase was evaporated and the residue dissolved in $100 \mu \mathrm{l}+1 \mathrm{ml}$ ) of which $2 \mu 1$ were injected into a research gas chromatograph $5750 \mathrm{G}$ equipped with a flame ionisation detector (Hewlett Packard, D-6000 Frankfurt/Main 56).

Conditions of the gas chromatograph:

glass column $115 \mathrm{~cm}$, column temperature $240^{\circ} \mathrm{C}$, stationary phase 3\% OV-101 on Gas Chrom Q, 100-120 mesh (Applied 
Table 4: Protocol of the Labtronic ES 25 System

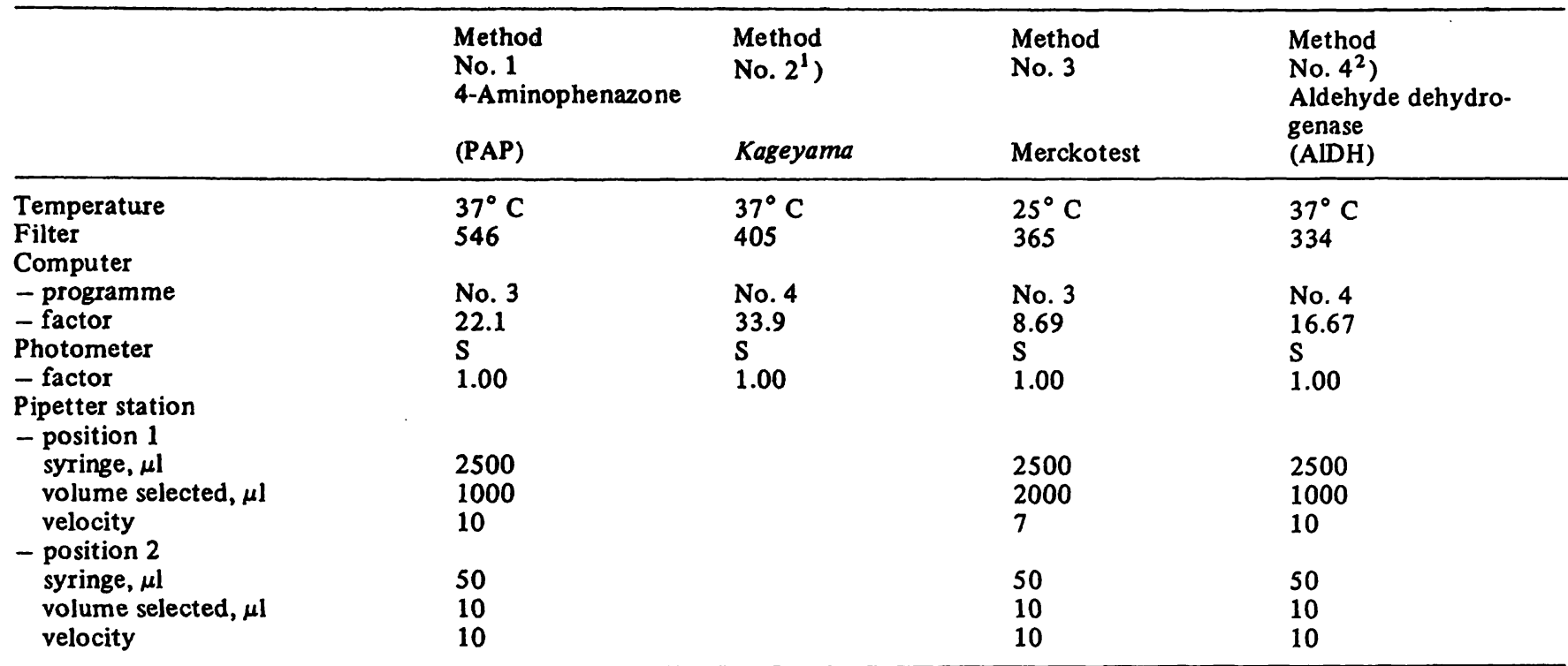

1) Pipetting was performed manually with Eppendorf pipets according to the manufacturer's instructions. This method uses a sample blank without cholesterol oxidase.

2) 2 measurements, the first before and the second 10 minutes after the addition of $20 \mu$ l cholesterol oxidase. Mixing was performed with a mini-mix (Vitatron GmbH, D-5000 Köln 60).

Science Lab. Inc., catalogue No. 12702, distributed by Serva International, D-6900 Heidelberg), carrier-gas $\mathrm{N}_{2}(30 \mathrm{ml} / \mathrm{min})$. The cholesterol concentration of the unknown samples was calculated from the regression line of the peak heights of standard solutions.

\section{Standard solutions and calibration factors}

Results were calculated with the factor supplied by the manufacturers for method 1-3.

With method No. 4 the coefficient of absorbance $\epsilon 334 \mathrm{~nm}=$ $6.18 \times 10^{6} \mathrm{~cm}^{2} / \mathrm{mol}(16)$ was used. Unter these conditions the cholesterol standard $(5.00 \mathrm{mmol} / \mathrm{l})$ according to Richmond was recovered almost $100 \%(\overline{\mathrm{x}}=5.04$, coefficient of variation $1.64 \%$, $\mathrm{n}=28$ ).

Method 5 and 6 were referred to a standard solution prepared according to Richmond (15): $1450.02 \mathrm{mg}$ cholesterol (purity $99 \%$ ) were dried and dissolved in $50 \mathrm{ml}$ propanol-2, of which $20 \mathrm{ml}$ were combined with $15 \mathrm{ml}$ Triton $X-100$ and then evaporated at $70^{\circ} \mathrm{C}$ under vacuum. The residue is transferred into a $100 \mathrm{ml}$ volumetric flask with $40 \mathrm{ml}$ hot, bidistilled water and $5 \times 7 \mathrm{ml} 200 \mathrm{~g} / 1$ albumin solution. At room temperature bidistilled water is added up to the $100 \mathrm{ml}$ mark. One (or 2$) \mathrm{ml}$ of this stock solution are mixed with 2 (or 1 ) $\mathrm{ml}$ of $70 \mathrm{~g} / 1$ albumin solution to give a solution containing 5 (or 10) $\mathrm{mmol} / \mathrm{l}$ cholesterol. This working standard solution is stable at $4^{\circ} \mathrm{C}$ for one month. For the GC procedure cholesterol was dried and directly dissolved in ethyl acetate. No significant difference was found between the cholesterol used and standard material supplied by the National Bureau of Standards (Washington, D.C., ÚSA).

The working standard was also used as a control in all other methods (except GC).

Method No. 7 was referred to Precilip.

Method No. 8 (Liebermann-Burchard, SMA 12/60) was referred to Hyland reference serum (Travenol, D-8000 Munich, catalogue No. HD 045-022, lot No. 3656N002BA). Under this condition a value of $4.59 \pm 0.1 \mathrm{mmol} / 1(n=28)$ was found in the cholesterol standard according to Richmond.

\section{Interference study}

The test for interference was similar to that proposed by Staehler et al. (17). Ten or $100 \mathrm{ml}$ of a large serum pool were mixed with the substance of interest as indicated in table 9. These samples were analyzed in various series together with several contro samples (no substance added). The results from the control samples were used to calculate the mean and the \pm 3 .s-range $(s=$ standard deviation). Bilirubin interference was studied by dissolving $6 \mathrm{mg}$ bilirubin (E. Merck AG, catalogue No. 245 19) in $500 \mu \mathrm{l}$ bidist. $\mathrm{H}_{2} \mathrm{O}$ and $25 \mu \mathrm{l} \mathrm{NaOH}(1 \mathrm{~mol} / \mathrm{l})$. When the bilirubin was completely dissolved, albumin $(70 \mathrm{~g} / 1)$ was added to $2 \mathrm{ml}$. An aliquot $(100 \mu \mathrm{l})$ of this solution was mixed with $1000 \mu \mathrm{l}$ serum. Bilirubin was omitted in the control experiments.

\section{Reagents}

Propanol-2 (catalogue No. 9634), cholesterol (No. 24622), ethyl acetate (No. 9623) and cyclohexane (No. 2828) were purchased from E. Merck AG (D-6100 Darmstadt), Triton X-100 (No. 37238) from Serva (D-6900 Heidelberg), albumin (No. ORDH) from Behringwerke AG (D-3550 Marburg), concentrated acetic acid (No. 33209) from Riedel de Haen (D-3016 Seelze) and $\mathrm{KOH}$ in ethanol from Boehringer Mannheim (D-6800 Mannheim, catalogue No. 15916).

\section{Control materials}

Precilip (catalogue No. 125059) and Preciset (catalogue No. 125512) were purchased from Boehringer Mannheim (D-6800 Mannheim), Seronorm (catalogue No. NYCO 350053) from Dr. Molter GmbH (D-6900 Heidelberg).

\section{Statistical methods}

The results of the correlation study were computed by main component analysis $(18,19)$. Serum samples were randomly selected from patients of our hospital. Other statistical methods were used according to 1.c (20).

\section{Results}

\section{Imprecision}

The GC and Kageyama methods had the highest imprecision from day to day (tab. 5), followed by the SMA procedure, whereas all enzymatic methods had 
Table 5: Precision from day to day of the various methods for the determination of the cholesterol concentration.

\begin{tabular}{|c|c|c|c|c|c|c|c|c|c|c|}
\hline $\begin{array}{l}\text { Control material } \\
\text { (Lot number) }\end{array}$ & $\begin{array}{l}\text { Assigned } \\
\text { value } \\
\text { [mmol/1] } \\
\text { (range) }\end{array}$ & $\begin{array}{l}\text { 4-Amino- } \\
\text { phena- } \\
\text { zone } \\
\text { (PAP) }\end{array}$ & $\begin{array}{l}\text { Kage- } \\
\text { yama }\end{array}$ & $\begin{array}{l}\text { Mercko- } \\
\text { test }\end{array}$ & $\begin{array}{l}\text { Alde- } \\
\text { hyde } \\
\text { dehydro- } \\
\text { genase } \\
\text { (AIDH) }\end{array}$ & ABA & GENT & $\mathbf{A A}$ & SMA & GC \\
\hline Standard solution & 5.00 & $\begin{array}{l}\left.5.03^{4}\right) \\
2.1 \\
(28)\end{array}$ & $\begin{array}{l}5.45 \\
7.0 \\
(28)\end{array}$ & $\begin{array}{l}4.94 \\
1.4 \\
(28)\end{array}$ & $\begin{array}{l}5.04 \\
1.5 \\
(28)\end{array}$ & - & - & $\begin{array}{l}5.39 \\
1.5 \\
(28)\end{array}$ & $\begin{array}{l}4.59 \\
2.9 \\
(28)\end{array}$ & \\
\hline Preciset (1067544) & 3.88 & $\begin{array}{l}4.07 \\
1.8 \\
(28)\end{array}$ & $\begin{array}{l}4.25 \\
7.4 \\
(28)\end{array}$ & $\begin{array}{l}4.06 \\
2.1 \\
(28)\end{array}$ & $\begin{array}{l}4.17 \\
2.8 \\
(28)\end{array}$ & $\begin{array}{l}4.16 \\
1.9 \\
(28)\end{array}$ & $\begin{array}{l}4.23 \\
3.2 \\
(28)\end{array}$ & $\begin{array}{l}3.96 \\
2.3 \\
(28)\end{array}$ & $\begin{array}{l}3.48 \\
2.9 \\
(28)\end{array}$ & $\begin{array}{l}4.20 \\
6.15 \\
(8)\end{array}$ \\
\hline Seronorm (128) & $\begin{array}{l}\left.2.80^{2}\right) \\
(2.49-3.11)\end{array}$ & $\begin{array}{l}2.25 \\
2.3 \\
(30)\end{array}$ & $\begin{array}{l}2.41 \\
12.5 \\
(30)\end{array}$ & $\begin{array}{l}1.81 \\
2.8 \\
(30)\end{array}$ & $\begin{array}{l}2.25 \\
1.0 \\
(14)\end{array}$ & $\begin{array}{l}2.28 \\
2.9 \\
(30)\end{array}$ & $\begin{array}{l}2.39 \\
1.4 \\
(30)\end{array}$ & $\begin{array}{l}2.14 \\
1.2 \\
(30)\end{array}$ & $\begin{array}{l}2.64 \\
4.0 \\
(30)\end{array}$ & $\begin{array}{l}2.26 \\
11.4 \\
(9)\end{array}$ \\
\hline Precilip (455 A) & $\begin{array}{l}\left.3.54^{1}\right) \\
(3.04-4.04) \\
\left.4.00^{2}\right) \\
(3.44-4.56)\end{array}$ & $\begin{array}{l}3.83 \\
3.1 \\
(30)\end{array}$ & $\begin{array}{l}3.84 \\
8.4 \\
(30)\end{array}$ & $\begin{array}{l}3.44 \\
2.5 \\
(30)\end{array}$ & $\begin{array}{l}3.49 \\
2.6 \\
(30)\end{array}$ & $\begin{array}{l}3.71 \\
2.2 \\
(14)\end{array}$ & $\begin{array}{l}3.85 \\
2.0 \\
(30)\end{array}$ & - & $\begin{array}{l}3.92 \\
3.0 \\
(30)\end{array}$ & $\begin{array}{l}3.76 \\
14.2 \\
(5)\end{array}$ \\
\hline Kontrollogen L (452 A) & $\begin{array}{l}\left.3.51^{1}\right) \\
(2.84-4.03) \\
\left.3.67^{2}\right) \\
(3.13-4.21) \\
\left.3.41^{3}\right) \\
(3.02-3.80)\end{array}$ & $\begin{array}{l}3.27 \\
2.5 \\
(30)\end{array}$ & $\begin{array}{l}3.84 \\
7.7 \\
(30)\end{array}$ & $\begin{array}{l}3.10 \\
2.1 \\
(30)\end{array}$ & $\begin{array}{l}3.34 \\
1.9 \\
(30)\end{array}$ & $\begin{array}{l}3.35 \\
1.3 \\
(30)\end{array}$ & $\begin{array}{l}3.64 \\
1.1 \\
(30)\end{array}$ & $\begin{array}{l}3.21 \\
1.9 \\
(30)\end{array}$ & $\begin{array}{l}3.76 \\
2.6 \\
(30)\end{array}$ & \\
\hline
\end{tabular}

1) for Kageyama method

$\left.{ }^{2}\right)$ for SMA-method

3) for 4-aminophenazone (PAP)-method

${ }^{4}$ ) mean value, coefficient of variation (number of contributing values)

almost the same, good precision under the experimental conditions chosen, with a mean coefficient of variation of about $2.0 \%$.

\section{Accuracy}

The relation between various cholesterol concentrations and the absorbance difference obtained (linearity-test) was checked with dilutions from the stock standard solution. No relevant deviation $(<1 \%)$ in the range investigated (up to $15 \mathrm{mmol} / \mathrm{l}$ ) was seen with the 4-aminophenazone, Merck, aldehyde dehydrogenase and ABA method. The range of linearity was slightly reduced with the Kageyama (13 mmol/l), GENT (12 mmol/l), SMA $(13 \mathrm{mmol} / \mathrm{l}), \mathrm{AA}(10 \mathrm{mmol} / \mathrm{l})$ and $\mathrm{GC}(12 \mathrm{mmol} / \mathrm{l})$ method.
For the intermethod comparison the GC method was included in this study as a non-enzymatic procedure of relatively high specificity. The correlation data are summarized in table 6. All enzymatic procedures showed a similar correlation with the GC-method; the highest negative bias was obtained with the Merckotest method.

For graphical presentation of the correlation data the GC method is less suited because of its high imprecision (table 5). For this purpose we preferred the 4-aminophenazone method (method No. 1 in table 1) which is now mostly applied in clinical chemistry. Its correlation with the GC-method is shown in table 6 and figure 1. Under these conditions the 4-aminophenazone method correlated well (tab. 7, fig. 1) with the Merckotest, alde-

Table 6: The correlation between the GC method ( $x$ - values) and all other procedurës ( $y_{i}$-values) for the determination of the cholesterol concentration in sera from various patients. All figures were calculated by principle component analysis according to l.c. (18).

\begin{tabular}{lllll}
\hline Method & $\mathrm{a}$ (intercept) & $\mathrm{b}$ (slope) & $\mathrm{r}$ & n (pairs of results) \\
\hline 4-Aminophenazone (PAP) & -0.205 & 1.040 & 0.963 & 115 \\
Kageyama & +0.211 & 1.045 & 0.875 & 115 \\
Merckotest & -0.435 & 1.039 & 0.952 & 115 \\
Aldehyde dehydrogenase (AlDH) & -0.313 & 1.048 & 0.946 & 115 \\
ABA & -0.339 & 1.057 & 0.939 & 115 \\
GENT & +0.032 & 1.027 & 0.952 & 115 \\
AA & -0.042 & 1.007 & 0.953 & 115 \\
SMA & +1.220 & 0.803 & 0.855 & 109 \\
\hline
\end{tabular}


Table 7: The correlation between the 4-aminophenazone (PAP) method ( $x$-values) and all other procedures ( $y_{i}$-values) for the determination of the cholesterol concentration in sera from various patients. All figures were calculated by principle component analysis according to 1.c. (18).

\begin{tabular}{lllllll}
\hline Method & $\overline{\mathbf{x}}$ & $\overline{\mathbf{y}}$ & $\mathrm{a}$ (intercept) & $\mathrm{b}$ (slope) & $\mathrm{r}$ & $\mathrm{n}$ \\
\hline Kageyama & 4.80 & 5.20 & -0.28 & 1.141 & 0.893 & 165 \\
Merckotest & 4.80 & 4.56 & -0.28 & 1.009 & 0.983 & 165 \\
Aldehyde dehydrogenase & 4.80 & 4.72 & -0.08 & 1.000 & 0.982 & 165 \\
(AlDH) & & & & & \\
ABA & 4.80 & 4.96 & +0.17 & 0.997 & 0.981 & 165 \\
GENT & 4.80 & 4.73 & -0.18 & 1.023 & 0.975 & 164 \\
AA & 4.80 & 4.79 & +0.15 & 0.967 & 0.988 & 165 \\
SMA & 4.80 & 5.09 & +1.01 & 0.850 & 0.894 & 159 \\
GC & 4.75 & 4.76 & +0.38 & 0.922 & 0.963 & 115 \\
\hline
\end{tabular}

hyde dehydrogenase, ABA, GENT, AA and GC procedures. The correlation with the Kageyama and SMA cannot be accepted. With Merckotest the arithmetic mean for the results from all patients was lower than with the 4aminophenazone method. The histogram in figure 2 shows that this effect is not simply due to a parallel shift of the whole distribution pattern by a constant negative bias.

In addition, with some control sera, the Merckotest led to the lowest mean values, whereas with standard solutions the recovery was comparable to those of the other enzymatic procedures.

The esterase reaction was not actually tested. However, the good correlation between the Liebermann-Burchard or the GC method with its alkaline saponification step, and the other procedures using the enzymatic hydrolysis, indicates that the esterase action may have been sufficient in all tests used. The differences observed with control materials (table 5) could be explained by the various esterase sources which are chosen by the manufacturers.

\section{Interference from endogenous substances}

Assuming that the GC method is not disturbed by elevated serum concentrations of triglycerides, hemoglobin or bilirubin, the results of this procedure were compared with all other methods. In figure 3 the difference (in $\mathrm{mmol} / \mathrm{l}$ ) between both methods was plotted against the serum concentration of bilirubin. In the case of an interference the regression line should be above or below the middle line and have a slope. The \pm 3 stāndârd deviation line was calculated from the results obtained with sera which looked clear and were not considered to be contaminated by one of the three endogenous substances.

No interference was noticed from hemoglobin (up to a concentration of $7 \mathrm{~g} / \mathrm{l})$, or from turbidity caused by triglycerides (up to $12 \mathrm{mmol} / \mathrm{l}$ ) under the conditions reported in figure 3.

Zak (3) mentioned the potential reaction of bilirubin with peroxide which could lead to an underestimation in procedures using an indicator reaction for $\mathrm{H}_{2} \mathrm{O}_{2}$. However, a distinct disturbance by bilirubin was only noticed with the Liebermann-Burchard method (fig. 3). This overestimation of the cholesterol concentration in the presence of bilirubin is well known. In the presence of very high bilirubin levels added to 2 different sera (tab. 8), the 4-aminophenazone method appeared to slightly underestimate, and the Merck method to slightly overestimate, the cholesterol concentration.

Uric acid (up to $2000 \mu \mathrm{mol} / \mathrm{l}$ ) did not influence the cholesterol value in the enzymatic procedures.

\section{Interferences from exogenous substances}

50 various substances which represent the most common used drugs and anticoagulants $(17,20)$ were added in high, but relevant doses to pooled sera from several patients (tab. 9).

The anticoagulants did not interfere with any of the methods. No interferences were observed with the Kageyama (No. 2), aldehyde dehydrogenase (No. 4) and Liebermann-Burchard method (No. 8). Interferences with the SMA and Kageyama procedures could have been masked by the higher imprecision of these methods. The other methods were submitted to a further study in which the concentrations of the interfering substances added were varied (table 10). Most often the cholesterol concentration was underestimated. With hostacyclin an overestimation was observed with the Merckotest procedure (table $9+10$ ). The recovery of cholesterol in the presence of ascorbic acid and especially of $\alpha$-methyldopa was higher with the Merckotest than with other methods using Trinder's principle. The interference of ascorbic acid with Trinder's reaction is already known (23).

\section{Practicability}

The Liebermann-Burchard method has the disadvantage that it uses a strong acidic reaction medium. The Kageyama procedure has the most pipetting steps. The 

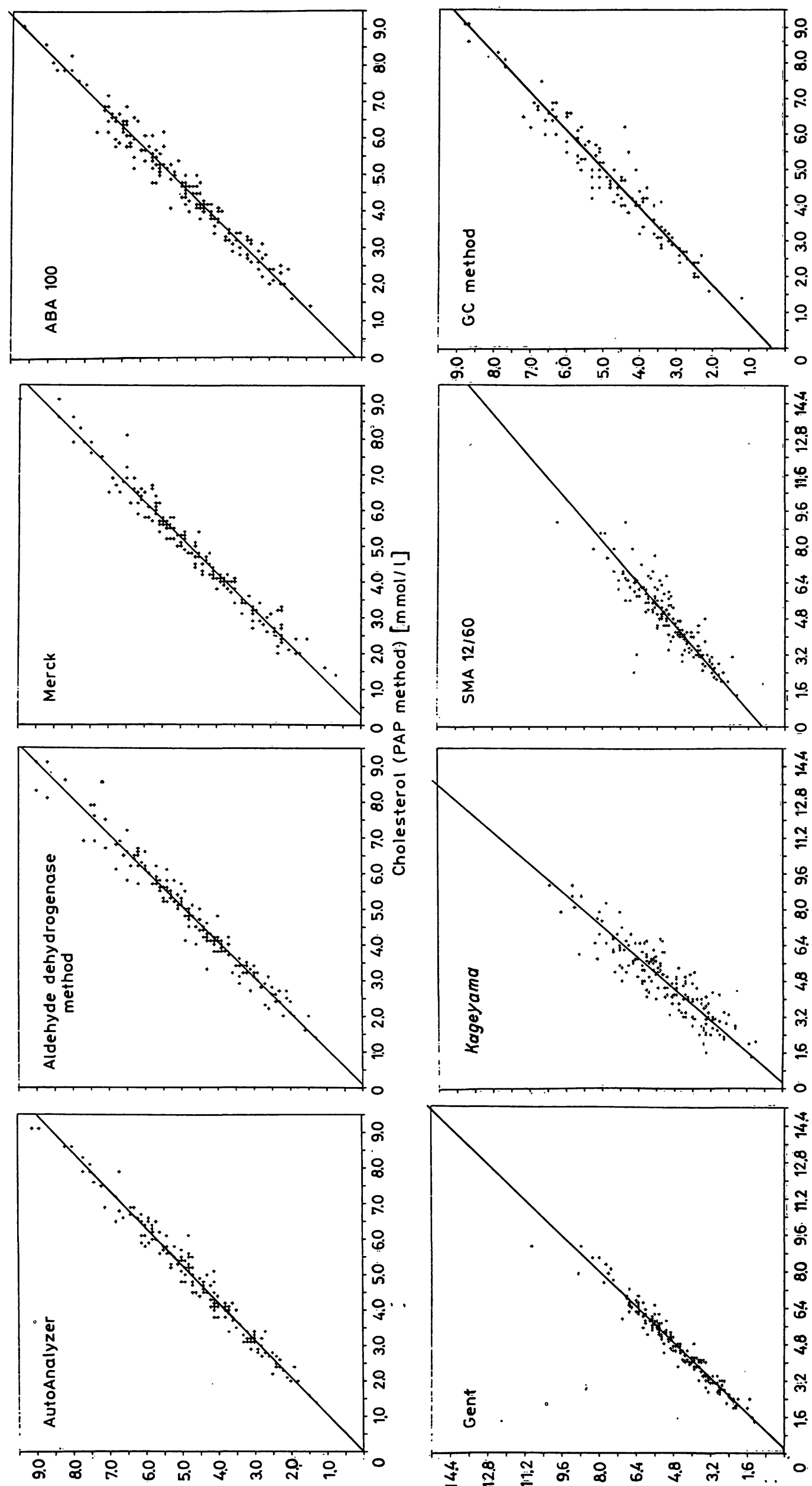

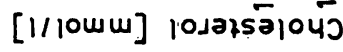

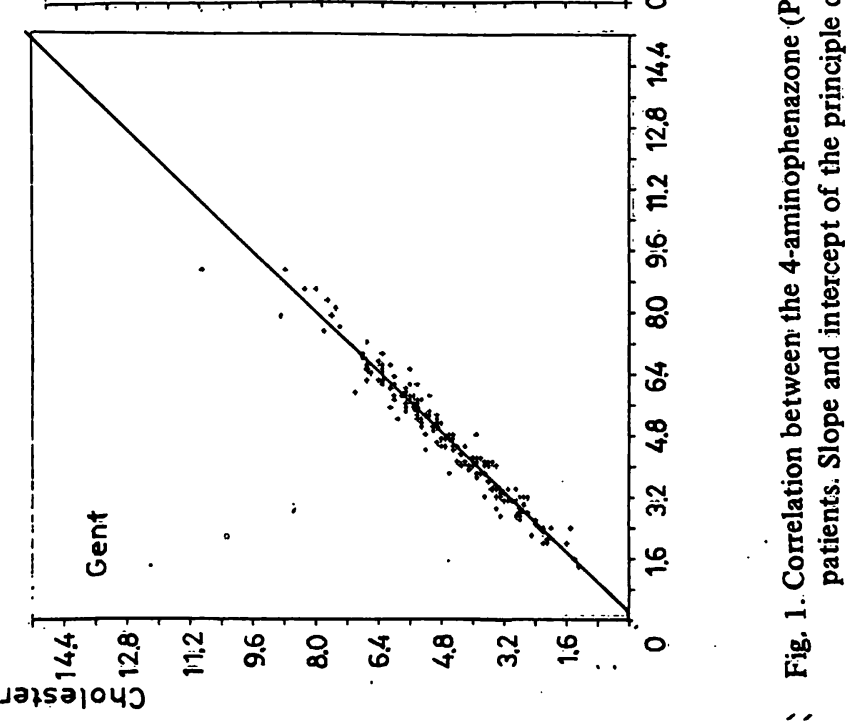

J. Clin. Chem. Clin. Biochem. / Vol. 17, 1979 / No. 8 

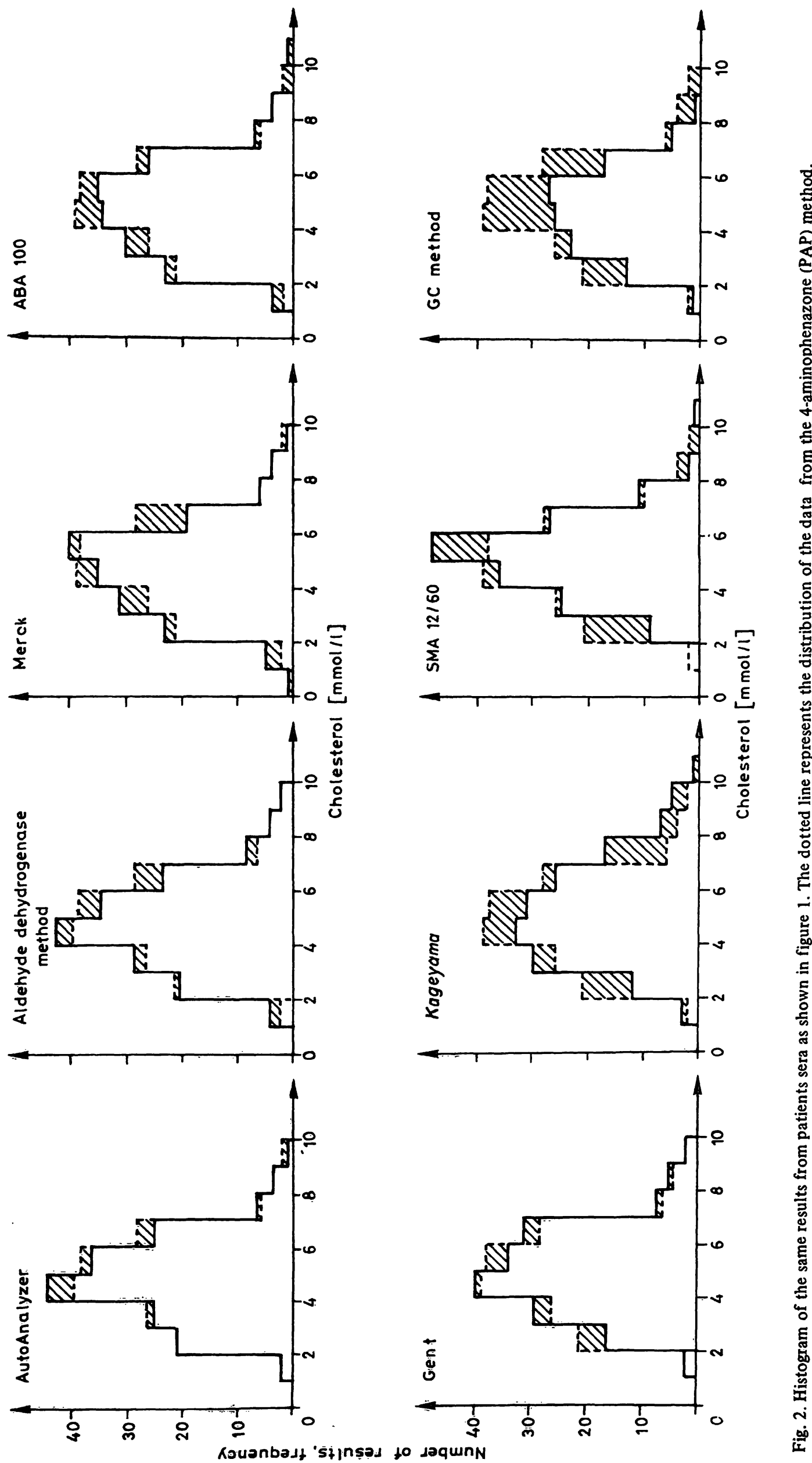

J. Clin. Chem. Clin. Biochem. / Vol. 17, 1979 / No. 8 


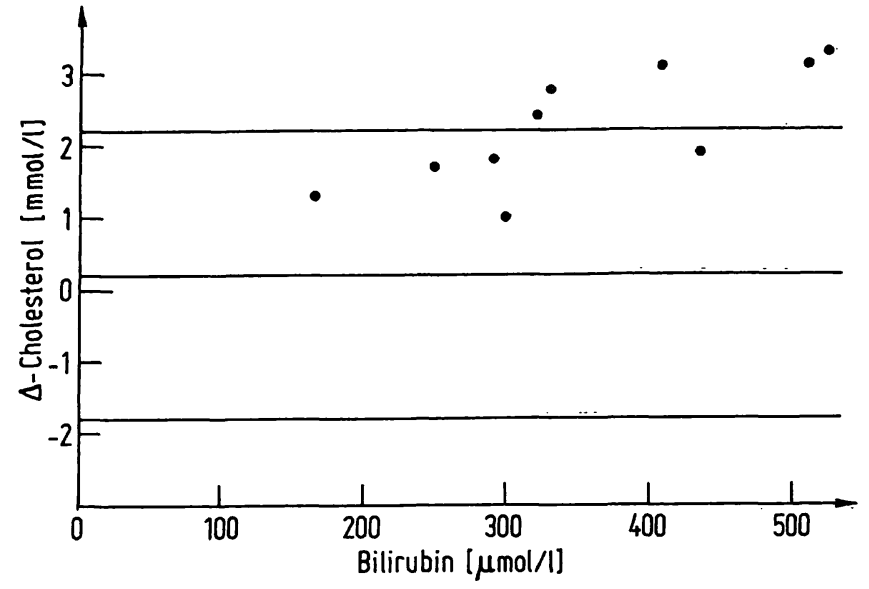

Fig. 3. Interference from bilirubin. The cholesterol concentration in various bilirubinemic sera was determined with the GC and the SMA methods. The difference ( $\Delta$ cholesterol) between the GC and the other method is plotted on the ordinate. The upper and lower borderline were calculated as the threefold standard deviation from the results ( $\Delta$ cholesterol) obtained with clear (non-bilirubinemic) sera (n, see table 7). other methods; except for GC, are equally practicable, since all reagents can be combined into one mixture and cholesterol oxidase be used to start the reaction. In the aldehyde dehydrogenase method, the well known absorption coefficient of $\mathrm{NAD}(\mathrm{P}) \mathrm{H}$ can be used to calculate the result.

The aldehyde dehydrogenase method requires either a sample blank, a first absorbance reading before the reaction has been started, or a kinetic measurement, which is a disadvantage with manual procedures.

\section{Conclusion}

In table 11 a decision matrix is established by weighting the results reported above. From this all methods could be ranked. As expected the lowest rank was obtained with method No. 2 and 8 .

Table 8: The influence of high bilirubin concentrations added to 2 different sera on various enzymatic procedures for the cholesterol determination. All figures are mean values ( $\mathrm{mmol} / \mathrm{l})$ from 2 determinations.

\begin{tabular}{lllcllr}
\hline $\begin{array}{l}\text { Serum number } \\
\text { Bilirubin, } \mu \text { mol/1 }\end{array}$ & 1 & 1 & & 2 & 2 & \\
& 11 & 390 & \% of control & 12 & 792 & $\%$ of control \\
\hline 4-Aminophenazone (PAP) & 3.64 & 3.50 & 96.1 & 3.60 & 3.10 & 86.1 \\
Merck & 3.63 & 3.78 & 104.1 & 3.28 & 3.50 & 106.7 \\
ABA & 3.90 & 3.87 & 99.2 & 3.62 & 3.61 & 99.7 \\
Aldehyde dehydrogenase & 3.90 & 3.88 & 99.5 & 3.54 & 3.55 & 100.3 \\
(AlDH) & & & & & & \\
\hline
\end{tabular}

Table 9: Recovery of cholesterol in human pooled sera containing various drugs. In the absence of any substance added a mean value and the range of 3 standard deviations was calculated from 15 determinations of the cholesterol concentration. Values outside this range are considered as due to interference (marked by an asterisk).

\begin{tabular}{|c|c|c|c|c|c|c|c|c|c|c|}
\hline \multirow[t]{2}{*}{ Trade name } & \multirow[t]{2}{*}{ I.N.N. $\left.{ }^{1}\right)$} & \multirow{2}{*}{$\begin{array}{l}\text { Concentration } \\
(\mathrm{mg} / \mathrm{l})\end{array}$} & \multicolumn{8}{|c|}{ Cholesterol concentration (mmol/l) } \\
\hline & & & PAP & Kageyama & $\begin{array}{l}\text { Mercko- } \\
\text { test }\end{array}$ & AlDH & $\mathbf{A B A}$ & GENT & $\mathbf{A A}$ & SMA \\
\hline $\begin{array}{l}\text { Amuno } \\
\text { Butazolidine }\end{array}$ & $\begin{array}{l}\text { indometacinum } \\
\text { phenylbuta- } \\
\text { zonum }\end{array}$ & $\begin{array}{r}30 \\
280\end{array}$ & $\begin{array}{l}5.35 \\
5.37\end{array}$ & $\begin{array}{l}5.83 \\
4.75\end{array}$ & $\begin{array}{l}5.22 \\
5.20\end{array}$ & $\begin{array}{l}5.34 \\
5.34\end{array}$ & $\begin{array}{l}5.38 \\
5.38\end{array}$ & $\begin{array}{l}5.70 \\
5.73\end{array}$ & $\begin{array}{l}5.68 \\
5.75\end{array}$ & $\begin{array}{l}6.6 \\
6.8\end{array}$ \\
\hline Metalcaptase & $\begin{array}{l}D \text {-penicil- } \\
\text { laminum }\end{array}$ & 960 & 5.12 & 6.54 & $4.68 *$ & 5.47 & 5.42 & 5.55 & 5.64 & 6.7 \\
\hline Prolixan & $\begin{array}{l}\text { azopropazon- } \\
\text { dihydrat }\end{array}$ & 250 & 5.39 & 6.17 & 5.05 & 5.36 & 5.67 & 5.64 & 5.73 & 6.8 \\
\hline $\begin{array}{l}\text { Resochin } \\
\text { Tanderil }\end{array}$ & $\begin{array}{l}\text { chloroquinum } \\
\text { oxyphenbuta- } \\
\text { zonum }\end{array}$ & $\begin{array}{r}60 \\
600\end{array}$ & $\begin{array}{l}5.37 \\
5.48\end{array}$ & $\begin{array}{l}7.05 \\
4.71\end{array}$ & $\begin{array}{l}5.23 \\
5.01\end{array}$ & $\begin{array}{l}5 . \overline{70} \\
5.58\end{array}$ & $\begin{array}{l}5.42 \\
5.42\end{array}$ & $\begin{array}{l}5.65 \\
5.49\end{array}$ & $\begin{array}{l}5.80 \\
5.55\end{array}$ & $\begin{array}{l}6.6 \\
6.9\end{array}$ \\
\hline $\begin{array}{l}\text { Aponal } \\
\text { Megaphen } \\
\text { Multum }\end{array}$ & $\begin{array}{ll}\text { doxepinum } & 1 \\
\text { phenothiazinum } & 1 \\
\text { chlordiazepo- } & 1 \\
\text { xidum } & \end{array}$ & $\begin{array}{l}150 \\
150 \\
160\end{array}$ & $\begin{array}{l}5.53 \\
5.41 \\
5.37\end{array}$ & $\begin{array}{l}6.24 \\
6.10 \\
4.64\end{array}$ & $\begin{array}{l}5.27 \\
5.10 \\
5.14\end{array}$ & $\begin{array}{l}5.38 \\
5.47 \\
5.39\end{array}$ & $\begin{array}{l}5.31 \\
5.37 \\
5.47\end{array}$ & $\begin{array}{l}5.66 \\
5.55 \\
5.64\end{array}$ & $\begin{array}{l}5.60 \\
5.70 \\
5.46\end{array}$ & $\begin{array}{l}7.0 \\
6.4 \\
6.3\end{array}$ \\
\hline Aspirin . & $\begin{array}{l}\text { acidum acety- } \\
\text { losalicylicum }\end{array}$ & 750 & $5.39^{\circ}$ & 6.03 & 5.15 & 5.26 & 5.53 & 5.70 & 5.68 & 7.0 \\
\hline Dolviran & $\begin{array}{l}\text { acidum acetylo- } 7 \\
\text { salicylicum, etc. }\end{array}$ & 780 & 5.69 & 4.98 & 5.14 & 5.24 & 5.40 & 5.75 & 5.64 & 5.7 \\
\hline Novalgin $^{2}$ ) & $\begin{array}{l}\text { novaminsul- } \\
\text { fonum }\end{array}$ & 900 & $4.44 *$ & 6.13 & 1.05* & 5.20 & 5.64 & $4.61^{*}$ & $5.21 *$ & 6.5 \\
\hline $\begin{array}{l}\text { Benemid } \\
\text { Uriovac } \\
\text { Zyloric }\end{array}$ & $\begin{array}{l}\text { probenecidum } 2 \\
\text { benzbromaronum } \\
\text { allopurinolum } 2\end{array}$ & $\begin{array}{l}260 \\
60 \\
250\end{array}$ & $\begin{array}{l}5.61 \\
5.66 \\
5.55\end{array}$ & $\begin{array}{l}5.70 \\
5.09 \\
5.97\end{array}$ & $\begin{array}{l}5.25 \\
5.24 \\
4.99\end{array}$ & $\begin{array}{l}5.38 \\
5.38 \\
5.49\end{array}$ & $\begin{array}{l}5.33 \\
5.40 \\
5.42\end{array}$ & $\begin{array}{l}5.70 \\
5.62 \\
5.6 .2\end{array}$ & $\begin{array}{l}5.68 \\
5.70 \\
5.55\end{array}$ & $\begin{array}{l}6.7 \\
6.5 \\
6.6\end{array}$ \\
\hline
\end{tabular}


Table 9: (continued)

\begin{tabular}{|c|c|c|c|c|c|c|c|c|c|c|}
\hline \multirow[t]{2}{*}{ Trade name } & \multirow[t]{2}{*}{ (.N.N.') } & \multirow{2}{*}{$\begin{array}{l}\text { Concentration } \\
(\mathrm{mg} / \mathrm{l})\end{array}$} & \multicolumn{8}{|c|}{ Cholesterol concentration (mmol/1) } \\
\hline & & & PAP & Kageyama & $\begin{array}{l}\text { Mercko- } \\
\text { test }\end{array}$ & AIDH & $\mathbf{A B A}$ & GENT & AA & SMA \\
\hline Angiografin & $\begin{array}{l}\text { acidum triiod- } \\
\text { benzoicum }\end{array}$ & 2600 & 5.57 & 4.61 & 5.23 & 5.58 & 5.38 & 5.62 & 5.70 & 6.8 \\
\hline Biligrafin & $\begin{array}{l}\text { adipinyltriiod- } \\
\text { anilidum }\end{array}$ & 1200 & 5.39 & 6.27 & 5.23 & 5.20 & 5.42 & 5.66 & 5.75 & 7.1 \\
\hline Urografin & $\begin{array}{l}\text { acidum triiod- } \\
\text { benzoicum }\end{array}$ & 1500 & 5.08 & 4.81 & 5.19 & 5.68 & 5.47 & 5.59 & 5.69 & 6.6 \\
\hline Binotal 500 & $\begin{array}{l}\text { aminobenzyl- } \\
\text { penicillinum }\end{array}$ & 900 & 5.61 & 6.27 & $4.41^{*}$ & 5.39 & 5.47 & 5.68 & 5.67 & 7.3 \\
\hline $\begin{array}{l}\text { Hostacyclin } \\
\text { Paraxin }\end{array}$ & $\begin{array}{l}\text { tetracyclinum } \\
\text { chlorampheni- } \\
\text { colum }\end{array}$ & $\begin{array}{l}200 \\
600\end{array}$ & $\begin{array}{l}5.57 \\
5.50\end{array}$ & $\begin{array}{l}4.64 \\
6.71\end{array}$ & $\begin{array}{l}5.69^{*} \\
5.06\end{array}$ & $\begin{array}{l}5.02 \\
5.30\end{array}$ & $\begin{array}{l}5.29 \\
5.49\end{array}$ & $\begin{array}{l}5.62 \\
5.60\end{array}$ & $\begin{array}{l}5.65 \\
5.68\end{array}$ & $\begin{array}{l}6.0 \\
6.5\end{array}$ \\
\hline Refobacin & gentamycinum & 120 & 5.46 & 6.92 & 5.07 & 5.28 & 5.55 & 5.65 & 5.72 & 6.3 \\
\hline Buscopan & $\begin{array}{l}\text { hyoscin-N-butyl- } \\
\text { brominum }\end{array}$ & $\cdot 300$ & 5.41 & 4.78 & 5.22 & 5.39 & 5.44 & 5.72 & 5.79 & 6.9 \\
\hline Cebion & $\begin{array}{l}\text { acidum } \\
\text { ascorbicum }\end{array}$ & 400 & $3.01 *$ & 5.66 & $3.45 *$ & 5.30 & 5.56 & $4.03^{*}$ & $3.16^{*}$ & 7.5 \\
\hline Polybion & $\begin{array}{l}\text { Vitamin B } \\
\text { complex }\end{array}$ & 12.9 & 5.35 & 6.00 & 5.20 & 5.13 & 5.44 & 5.64 & 5.67 & 6.0 \\
\hline Dipar & $\begin{array}{l}\text { phenylethyl- } \\
\text { biguanide }\end{array}$ & 220 & 5.75 & 5.59 & 5.23 & 5.24 & 5.38 & 5.73 & 5.63 & 5.9 \\
\hline $\begin{array}{l}\text { Euglucon } 5 \\
\text { Rastinon }\end{array}$ & $\begin{array}{l}\text { glibenclamidum } \\
\text { tolbutamidum }\end{array}$ & $\begin{array}{r}32 \\
480\end{array}$ & $\begin{array}{l}5.44 \\
5.22\end{array}$ & $\begin{array}{l}5.36 \\
4.71\end{array}$ & $\begin{array}{l}5.14 \\
4.97\end{array}$ & $\begin{array}{l}5.22 \\
5.45\end{array}$ & $\begin{array}{l}5.38 \\
5.44\end{array}$ & $\begin{array}{l}5.70 \\
5.63\end{array}$ & $\begin{array}{l}5.49 \\
5.71\end{array}$ & $\begin{array}{l}6.2 \\
6.8\end{array}$ \\
\hline Dulcolax & bisacodylum & 40 & 5.70 & 4.88 & 5.13 & 5.30 & 5.38 & 5.77 & 5.71 & 6.0 \\
\hline Durenat & $\begin{array}{l}\text { sulfanilamido- } \\
\text { pyrimidinum }\end{array}$ & 231 & 5.72 & 5.02 & 5.13 & 5.07 & 5.36 & 5.73 & 5.65 & 6.2 \\
\hline Endoxan & $\begin{array}{l}\text { cyclophosphami- } \\
\text { dum }\end{array}$ & $\mathrm{i}-240$ & 5.68 & 5.59 & 5.23 & 5.22 & 5.36 & 5.73 & 5.72 & 5.8 \\
\hline Methotrexat & $\begin{array}{l}\text { acidum methyl- } \\
\text { pteroylglutami- } \\
\text { nicum }\end{array}$ & 500 & 5.59 & 6.13 & 5.08 & 5.32 & 5.39 & 5.58 & 5.68 & 6.5 \\
\hline Intensain & carbocromenum & 900 & 5.44 & 4.88 & 5.17 & 5.45 & 5.42 & 5.73 & 5.63 & 6.0 \\
\hline Furadantin & nitrofurantoinum & m 98 & 5.26 & 4.37 & 5.17 & 5.24 & 5.47 & 5.73 & 5.57 & 5.6 \\
\hline Lanicor & digoxinum & 0.1 & 5.26 & 5.25 & 5.17 & 5.41 & 5.47 & 5.73 & 5.54 & 6.0 \\
\hline Lasix & furosemidum & 60 & 5.35 & 4.95 & 5.12 & 5.68 & 5.40 & 5.65 & 5.47 & 5.7 \\
\hline Luminal & $\begin{array}{l}\text { acidum phenyl- } \\
\text { aethylbarbituric }\end{array}$ & $\begin{array}{l}352 \\
\text { cum }\end{array}$ & 5.37 & 5.42 & 5.13 & 5.36 & 5.42 & 5.64 & 5.54 & 6.6 \\
\hline Macrodex $6 \%$ & dextranum $6 \% 6$ & 6000 & 5.62 & 6.38 & 5.17 & 5.32 & 5.37 & 5.59 & 5.51 & 5.5 \\
\hline $\begin{array}{l}\text { Modenol } \\
\text { Presinol }\end{array}$ & $\begin{array}{l}\text { thiabutazide, etc. } \\
\text { methyldopa }\end{array}$ & $\begin{array}{r}.440 \\
400\end{array}$ & $\begin{array}{l}5.39 \\
3.05^{*}\end{array}$ & $\begin{array}{l}6.44 \\
6.61\end{array}$ & $\begin{array}{l}5.11 \\
4.51^{*}\end{array}$ & $\begin{array}{l}5.38 \\
5.53\end{array}$ & $\begin{array}{l}5.42 \\
5.48\end{array}$ & $\begin{array}{l}5.53 \\
3.72 *\end{array}$ & $\begin{array}{l}5.67 \\
3.00 *\end{array}$ & $\begin{array}{l}7.1 \\
7.0\end{array}$ \\
\hline Nicobion & nicotinamidum & 40 & 5.50 & 6.24 & 5.09 & 5.30 & 5.42 & 5.71 & 5.68 & 6.3 \\
\hline Novadral & norfenefrinum & 2.4 & 5.17 & 5.72 & 5.19 & 5.39 & 5.46 & 5.65 & 5.67 & 6.5 \\
\hline Solu-Decortin & prednisolonum & 8 & 5.24 & 6.10 & 5.23 & 5.58 & 5.48 & 5.65 & 5.68 & 6.6 \\
\hline Marcumar & $\begin{array}{l}\text { phenprocoumo- } \\
\text { num }\end{array}$ & 80 & 5.37 & 6.03 & 5.13 & 5.41 & 5.37 & 5.51 & 5.63 & 6.3 \\
\hline $\begin{array}{l}\text { Na-Citrat } \\
\text { Liquemin } \\
\text { Na-Fluorid } \\
\text { Na-Oxalat } \\
\text { EDTA }\end{array}$ & $\begin{array}{ll}\text { Na-citrate } & \text { S } \\
\text { Na-heparinat } & \\
\text { Na-fluoride } & 2 \\
\text { Na-oxalate } & 2 \\
\text { Titriplex III } & 1\end{array}$ & $\begin{array}{r}5000 \\
750 \\
2000 \\
2000 \\
1000\end{array}$ & $\begin{array}{l}5.24 \\
5.38 \\
5.41 \\
5.37 \\
5.53\end{array}$ & $\begin{array}{l}5.76 \\
6.24 \\
6.58 \\
7.12 \\
6.47\end{array}$ & $\begin{array}{l}5.20 \\
4.98 \\
4.95 \\
5.10 \\
5.20\end{array}$ & $\begin{array}{l}5.32 \\
5.55 \\
5.47 \\
5.43 \\
5.02\end{array}$ & $\begin{array}{l}5.42 \\
5.37 \\
5.42 \\
5.40 \\
5.40\end{array}$ & $\begin{array}{l}5.60 \\
5.60 \\
5.63 \\
5.64 \\
5.73\end{array}$ & $\begin{array}{l}5.61 \\
5.65 \\
5.61 \\
5.57 \\
5.63\end{array}$ & $\begin{array}{l}7.3 \\
7.1 \\
6.7 \\
7.3 \\
6.8\end{array}$ \\
\hline Aldactone & spirolactonum & 20 & 5.57 & 6.10 & 5.24 & 5.39 & 5.29 & 5.73 & 5.68 & 6.6 \\
\hline
\end{tabular}

\footnotetext{
1) International non-proprietary names as proposed by the WHO (21).

2) Data are not considered in table 10, since clinically.not relevant. This substance is rapidly metabolized and cannot be measured in significant blood concentrations (25).
} 
Table 10: Interference in enzymatic procedures for the determination of cholesterol by varying concentrations of certain substances.

\begin{tabular}{|c|c|c|c|c|c|}
\hline \multicolumn{2}{|l|}{ Method } & \multirow{2}{*}{$\begin{array}{l}\text { PAP } \\
\text { Cholesterol } \\
\text { (mimol/1) }\end{array}$} & \multirow[t]{2}{*}{ Merckotest } & \multirow[t]{2}{*}{ GENT } & \multirow[t]{2}{*}{$\mathbf{A A}$} \\
\hline Interfering Substance & $\begin{array}{l}\text { Concentration in the sample } \\
(\mathrm{mg} / \mathrm{l})\end{array}$ & & & & \\
\hline $\begin{array}{l}\text { Ascorbic acid up to } 0.7 \mathrm{mmol} / 1^{1} \text { ) } \\
\text { (overdosage up to } 1.4)(24)\end{array}$ & $\begin{array}{c}0 \\
50(0.28 \mathrm{mmol} / \mathrm{l}) \\
100(0.57 \mathrm{mmol} / \mathrm{l}) \\
200(1.14 \mathrm{mmol} / 1) \\
300(1.70 \mathrm{mmol} / 1) \\
400(2.27 \mathrm{mmol} / \mathrm{l})\end{array}$ & $\begin{array}{l}5.42 \\
4.95 \\
4.38 \\
4.33 \\
4.04 \\
3.14\end{array}$ & $\begin{array}{l}4.97 \\
4.79 \\
4.48 \\
4.37 \\
4.13 \\
3.49\end{array}$ & $\begin{array}{l}5.80 \\
5.53 \\
5.19 \\
5.09 \\
4.89 \\
4.24\end{array}$ & $\begin{array}{l}5.60 \\
5.23 \\
4.76 \\
4.67 \\
4.40 \\
3.68\end{array}$ \\
\hline Presinol up to $\left.193 \mathrm{mg} / \mathrm{l}^{1}\right)(26)$ & $\begin{array}{r}0 \\
50 \\
100 \\
200 \\
300 \\
400\end{array}$ & $\begin{array}{l}5.42 \\
5.06 \\
4.69 \\
3.96 \\
3.18 \\
2.72\end{array}$ & $\begin{array}{l}4.97 \\
4.94 \\
4.87 \\
4.54 \\
4.27 \\
4.24\end{array}$ & $\begin{array}{l}5.80 \\
5.49 \\
5.13 \\
4.45 \\
3.63 \\
3.18\end{array}$ & $\begin{array}{l}5.60 \\
5.16 \\
4.80 \\
4.03 \\
3.26 \\
2.78\end{array}$ \\
\hline $\begin{array}{l}\left.\text { Binotal up to } 300 \mathrm{mg} / 1^{1}\right) \\
(28,29)\end{array}$ & $\begin{array}{r}0 \\
200 \\
400 \\
600 \\
900\end{array}$ & & $\begin{array}{r}4.97 \\
4.42 \\
3.45 \\
2.64 \\
2.27\end{array}$ & . & \\
\hline $\begin{array}{l}\left.\text { Hostacyclin up to } 8 \mathrm{mg} / \mathrm{l}^{1}\right) \\
(28,29)\end{array}$ & $\begin{array}{r}0 \\
5 \\
10 \\
20 \\
50 \\
200\end{array}$ & - & $\begin{array}{l}5.42 \\
5.42 \\
5.46 \\
5.49 \\
5.65 \\
5.98\end{array}$ & & \\
\hline $\begin{array}{l}\left.\text { Metalcaptase up to } 10 \mathrm{mg} / 1^{1}\right) \\
(30,31)\end{array}$ & $\begin{array}{r}0 \\
10 \\
50 \\
100 \\
500\end{array}$ & & $\begin{array}{l}5.42 \\
5.36 \\
4.54 \\
4.64 \\
3.99\end{array}$ & . & \\
\hline
\end{tabular}

1) Serum concentration under therapeutic conditions.

Table 11: Comparison of the various methods by weighting the quantitative data from table 3-6 and figure 3.

\begin{tabular}{|c|c|c|c|c|c|c|c|c|}
\hline Method & $\begin{array}{l}1 \\
\text { PAP }\end{array}$ & $\begin{array}{l}2 \\
\text { Kageyama }\end{array}$ & $\begin{array}{l}3 \\
\text { Mercko- } \\
\text { test }\end{array}$ & $\begin{array}{l}4 \\
\text { AIDH }\end{array}$ & $\begin{array}{l}5 \\
\mathrm{ABA}\end{array}$ & $\begin{array}{l}6 \\
\text { GENT }\end{array}$ & $\begin{array}{l}7 \\
\mathrm{AA}\end{array}$ & $\begin{array}{l}8 \\
\text { SMA }\end{array}$ \\
\hline Precision $^{1}$ ) & ++ & - & ++ & + & ++ & ++ & ++ & + \\
\hline Correlation $^{2}$ ) & + & - & + & + & + & + & + & - \\
\hline Linearity & ++ & + & ++ & ++ & $+t$ & + & + & + \\
\hline Accuracy $^{3}$ ) & ++ & + & + & ++ & ++ & ++ & ++ & - \\
\hline $\begin{array}{l}\text { Lack of interference } \\
\text { from bilirubin } \\
\text { Lack of interferences }\end{array}$ & + & + & + & + & + & + & + & - \\
\hline $\begin{array}{l}\text { from exogenous sub- } \\
\text { stances }{ }^{4} \text { ) }\end{array}$ & ++ & $(+++)$ & + & +++ & +++ & ++ & ++ & $(+++)$ \\
\hline Practicability & +++ & + & +++ & ++ & +++ & +++ & +++ & ++ \\
\hline Sum of plus signs & 13 & 7 & 12 & 13 & 14 & 12 & 12 & 7 \\
\hline
\end{tabular}

1) Coefficient of variation $<3 \%++,<5 \%+,>5 \%-$

2) $\mathrm{r}^{2}>95.0 \%+,<95.0 \%-$ (coefficient of determination, taken from l.c. (18))

${ }^{3}$ ) estimated from table 5,6 and 7

${ }^{4}$ ) Table 9: no interference +++ , interferences from $\leqslant 3$ substances ++ , from more than 3 substances +

\section{References}

1. Burke, R. W., Diamond stone, B.I., Velapoldi, R. A. \& Mennis, O. (1974), Clin. Chem. 20, 794-801.

2. Perlstein, M. T., Thibert, R. J. \& Zak, B. (1975), Microchem. J. 20, 428-439

3. Zak, B. (1977), Clin. Chem. 23, 1201-1214.
4. Tonks, D. B. (1967), Clin. Biochem. 1, 12-29.

5. Krynski, I. A. \& Logan, J. E. (1968), Cliñ. Biochem. 2, 105-114.

6. Richmond, W. (1972), Internat. Congress Clin. Chem., Kopenhagen, Abstr. No. 325. . . 
7. Richmond, W. (1973), Clin. Chem. 19, 1350-1356.

8. Trinder, P. (1969), J. Clin. Pathol. 22, 158-164.

9. Kageyama, N. (1971), Clin. Chim. Acta 31, 421-426

10. Haeckel, R. \& Perlick, M. (1976), J. Clin. Chem. Clin. Biochem., 14, 411-414.

11. Harders, H. D. \& Helger, R. J. (1977), J. Clin. Chem. Clin. Biochem. 15, 159

12. Allain, C. C., Poon, L. S., Chen, C. S. G., Richmond, W. \& Fu, P. C. (1974), Clin. Chem. 20, 470-475

13. Abell, L. L., Levy, B. B., Brodie, B. B. \& Kendall, F. E. (1958), Standard Methods Clin. Chem. 2, 26-33

14. Siekmann, L., Hüskes, K. P. \& Breuer, H. (1976), Z. Anal. Chem. 279, 145-146.

15. Richmond, W. (1976), Clin. Chem. 22, 1579-1588.

16. Ziegenhorn, J. (1976), Clin. Chem. 22, 151-160.

17. Staehler, F., Munz, E. \& Kattermann, R. (1975), Dtsch. Med. Wochenschr. 100, 876-887

18. Feldmann, U., Schneider, B. \& Haeckel, R., in preparation.

19. Anderson, T. W. (1958): An introduction of multivariate stastistical analy sis. J. Wiley, New York.

20. Haeckel, R. (1975). Qualitätssicherung im medizinischen Laboratorium. Deutscher Ärzteverlag, Köln, 1-237

21. Haeckel, R. (1976), J. Clin. Chem. Clin. Biochem. 14, 165171.

22. Lexikon chemischer Kurzbezeichnungen von Arzneistoffen (1968), Govi Verlag GmbH, Frankfurt, 1-423.
23. Pesce, M. A. \& Bodourian, S. H. (1977) Clin. Chem. 23, 757-760.

24. Siest, G., Appel, W., Blijenberg, G. B., Capalaghi, B., Galteau, M. M., Heusghem, C., Hjelm, M., Lauer, K. L., Le Perron, B., Loppinet, V., Love, C., Royer, R. J., Tognomi, C. \& Wilding, P. (1978), J. Clin. Chem. Clin. Biochem. 16, 103-110.

25. Weiss, R., Brauer, J., Goertz, U. \& Petry, R. (1974), Drug Res. 24, 345-348.

26. Sourkes, Th., L., Murphy, G. F. \& Chavez-Lara, B. (1962), J. Med. Pharm. Chem. 5, 204-210.

27. Träger, S. (1973): Untersuchungen zur Pharmakokinetik des Ampicillins. Dissertation, Gießen.

28. Pelz, K., Herdter, F. \& Marcushen, M. (1977), Therapiewoche 27, 8585-8591.

29. Dimmling, Th. \& Wagner, W. H. (1965), Drug Res. 15, 1288-1292.

30. Patzschke, K., Wegner, L., Kaller, H. \& Horster, F. A. (1977), Z. Rheumatol. 36, 96-105.

31. Saetre, R. \& Rabenstein, L. (1978), Analyt. Chem. 2, 276280.

32. Assem, E., S., K. (1974), Curr. Med. Res. Opin. 2, 568-572

33. Paula, R., Sonntag, A., Martin, G. \& Kaiser, E. (1977), Med. Labor 30, 250-260.

Prof. Dr. R. Haeckel

Institut für Klinische Chemie

Medizinische Hochschule Hannover

Karl-Wiechert-Allee 9

D-3000 Hannover 61 